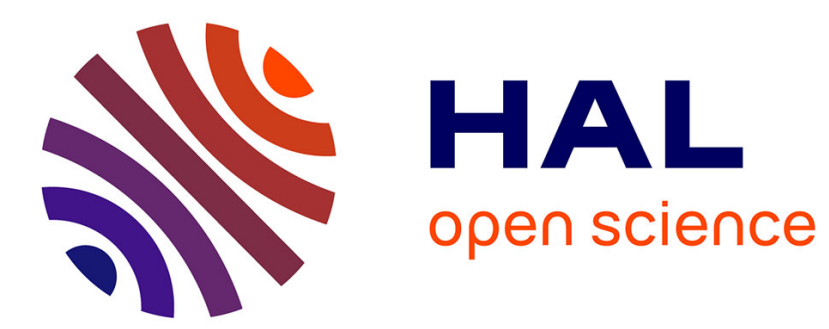

\title{
Islam in and out
}

\author{
Marie Miran-Guyon
}

\section{To cite this version:}

Marie Miran-Guyon. Islam in and out: Cosmopolitan patriotism and xenophobia among Muslims in Côte d'Ivoire. Africa, 2016, 86 (3), pp.447-471. 10.1017/S0001972016000334 . halshs-01406083v2

\section{HAL Id: halshs-01406083 \\ https://shs.hal.science/halshs-01406083v2}

Submitted on 23 Feb 2017

HAL is a multi-disciplinary open access archive for the deposit and dissemination of scientific research documents, whether they are published or not. The documents may come from teaching and research institutions in France or abroad, or from public or private research centers.
L'archive ouverte pluridisciplinaire HAL, est destinée au dépôt et à la diffusion de documents scientifiques de niveau recherche, publiés ou non, émanant des établissements d'enseignement et de recherche français ou étrangers, des laboratoires publics ou privés. 


\section{Africa}

http://journals.cambridge.org/AFR

Additional services for Africa:

Email alerts: Click here

Subscriptions: Click here

Commercial reprints: Click here

Terms of use : Click here

\section{ISLAM IN AND OUT: COSMOPOLITAN PATRIOTISM AND XENOPHOBIA AMONG MUSLIMS IN CÔTE D'IVOIRE}

Marie Miran-Guyon

Africa / Volume 86 / Issue 03 / August 2016, pp 447 - 471

DOI: 10.1017/S0001972016000334, Published online: 07 July 2016

Link to this article: http://journals.cambridge.org/abstract_S0001972016000334

How to cite this article:

Marie Miran-Guyon (2016). ISLAM IN AND OUT: COSMOPOLITAN PATRIOTISM AND XENOPHOBIAAMONG MUSLIMS IN CÔTE D'IVOIRE. Africa, 86, pp 447-471 doi:10.1017/S0001972016000334

Request Permissions : $\underline{\text { Click here }}$ 


\title{
ISLAM IN AND OUT: COSMOPOLITAN PATRIOTISM AND XENOPHOBIA AMONG MUSLIMS IN CÔTE D'IVOIRE
}

\author{
Marie Miran-Guyon
}

Islam began strange, and it will become strange again just like it was at the beginning, so blessed are the strangers. (Hadith of the Prophet Muhammad, Sahih Muslim (1/130))

Love of one's country is an article of faith. (Apocryphal Hadith, quoted by Cheikh Aboubacar Fofana ${ }^{1}$ )

\section{INTRODUCTION: ANTI-STRANGER IVOIRITÉ POLITICS AND ITS MUSLIM DISCONTENTS}

Muslims in Côte d'Ivoire have long been an idiom for Otherness. From a geopolitical standpoint, the country revolves around the Southern forest and coastal regions, where the plantation economy expanded from colonial times. In this congruent but diverse 'South', Northern Muslim in-migrants acted as the emblematic stranger in the process of forming a distinctly Southern 'Ivorian' self-consciousness and later a national identity. A new social grammar of Self and Other coalesced. The term 'autochthons' - shorthand for Southern autochthons - designated prime Ivorian citizens and natural leaders. The terms 'strangers' and 'foreigners', ${ }^{2}$ along with the reinvented ethnonym 'Dioula', ${ }^{3}$ were applied indistinctly to all latecomers sharing various identity markers, including Islam, with obvious prejudicial connotations (Chauveau and Dozon 1985; Dozon 1997; Dembélé 2002).

Struggles over 'autochthonous' belonging and the alienation of 'strangers' were stifled under the presidency of Félix Houphouët-Boigny, father of the independent nation. From the 1960 s to the 1980 s, nation building focused on the head of state,

MARIE MIRAN-GUYON is a lecturer at the École des Hautes Études en Sciences Sociales (EHESS) and Paris Sciences et Lettres (PSL), and a member of the Institut des Mondes Africains (IMAF) in Paris. Her research focuses on Islamic culture and Muslim society in Côte d'Ivoire. In a global comparative perspective, she also explores the plural Ivorian religious-scape and how it contributes to making and remaking the nation, past and present. Email: Marie.Miran@ehess.fr

${ }^{1}$ Interview with Cheikh Aboubacar Fofana, Côte d'Ivoire's national chief imam since 2006, 5 January 2008. For a biography of Fofana, see Miran-Guyon and Touré (2012).

${ }^{2}$ The French-Ivorian equivalents are étranger (a polysemous term for any non-local, regardless of origin), allogène (an external migrant originating from outside Côte d'Ivoire), and allochtone (an internal migrant from within Côte d'Ivoire).

${ }^{3}$ This is usually spelled Jula/Dyula in English (I side with the orthography of ethnic names used in today's Côte d'Ivoire). In the country's Northern savannah, Dioula has long meant a Mandeor Malinké-speaking trader. In the colonial South, the term came to encompass difference from an exogenous viewpoint. Inter alia, Dioula became synonymous with Muslim, including Muslims of non-Malinké origins. A Southern convert to Islam, for instance, would become Dioula (although few actually did) (Miran-Guyon 2012).

(C) International African Institute 2016 
his single party, and its extrovert, foreigner-friendly development ideology: there was little or no room for public debates on national identity. But nativist struggles were reignited in the wake of Houphouët's death in 1993 and his successors' brutal competition for power. ${ }^{4}$ The regime of Henri Konan Bédié (1994-99) conceptualized the ideology of ivoirité or 'Ivorians first'. This served to exclude Alassane Dramane Ouattara, a challenger of Northern and Muslim origins, from the electoral race on the alleged grounds that he was a foreigner. The successive regimes of Robert Gueï (1999-2000) and Laurent Gbagbo (2000-10) followed suit with ultranationalist, nativist discriminatory politics. Muslims and all those labelled 'strangers' were routinely reduced to de facto second-class citizens, with symbolic and physical violence. More than ever before, autochthons' political imaginary threw Muslims out to the margins of national relevance (among the many studies on Ivorian nativism, see Politique Africaine 2000; Akindès 2004; 2009; Banégas 2006; Marshall-Fratani 2006; Dozon 2011; McGovern 2011).

This article attempts to reverse this perspective by focusing on the interface between religion and national identity from within the Muslim community. It pays close attention to the oft-neglected, subaltern voice of Muslims/Dioula/ Northerners/strangers, as they are still commonly referred to in Ivorian public parlance (but see Gary Tounkara 2005; Savadogo 2005; Miran 2006a). It takes the ivoirité crises of the 1990 s as a point of departure but goes back in time to the colonial period and forward to the present to explore how and to what extent Muslims perceived themselves to be, or acted as, insiders or outsiders of the Ivorian nation and state.

The paper is divided into two main parts. The first part puts forward the alternative, anti-ivoirité, patriotic-cum-cosmopolitan narratives that a new Muslim leadership formulated to write Islam into national history. This leadership of young imams and Muslim intellectuals - to which Cheikh Aboubacar Fofana, quoted above, belonged - rose to public prominence in the 1990s. In a somewhat self-celebratory fashion, they claimed that Islam was both within and outside Côte d'Ivoire: outside and open to the wider world, but also within, genuinely rooted in the country and Ivorian. The second part nuances these discursive top-down accounts by focusing on grass-roots, demotic, day-to-day realities. It explores the complexities and contradictions of Muslim takes on 'flow and closure' in practice (Geschiere and Meyer 1999). These mirrored the community's internal diversity. Dioula from different Northern regions, Southern Muslims, non-national foreign Muslims, Muslims with diverse levels of sectarian obedience, all grappled differently with competition and division, as well as with solidarity. Positions changed with time and in scale. Over time, Ivorian Muslims showcased varying degrees of cosmopolitan patriotism but also of their own local xenophobia. The concluding section returns to the new Muslim leadership and their multifaceted endeavours to reconcile Muslim lived experiences with their cosmopolitan patriotic aspirations.

\footnotetext{
${ }^{4}$ This took place in the global context of the end of the Cold War, the democratic wave and neoliberal politics: a turn not specific to Côte d'Ivoire (African Studies Review 2006; Politique Africaine 2008). With seminal eloquence, Mbembe has analysed the dialogic African modes of writing the Self and Other as meta-narratives of difference and universalism, of nativism and cosmopolitanism (Mbembe 2002).
} 
The article ends with a short epilogue surveying the violent armed conflicts that took place from 2002 to 2011 and how Muslims were a part of them. The epilogue aims to bring the reader up to date and is not analytical per se. Indeed, war and the principle that 'might is right' temporarily abolished public debates on national identity. Later, concern for peace building and reconciliation took over from nation building. Installed in 2011, Alassane Dramane Ouattara is the country's first Muslim president. Yet, post-war Côte d'Ivoire is a long way from resolving thorny national issues such as those of belonging and alienation. Therefore, the questions discussed in this article are likely to remain central to Ivorian history for some time to come.

\section{COSMOPOLITAN PATRIOTS: THE MUSLIM ELITE'S ENDEAVOUR TO WRITE ISLAM INTO NATIONAL HISTORY}

In the late 1980s, a new Muslim elite group emerged in Côte d'Ivoire from the long-running encounter between a Western-trained, Francophone and middleor upper-class Muslim youth and a handful of Arabophone reform-minded preachers trained in Arab Islamic universities. These elites were mostly urban and Abidjan was their epicentre, but their audience had slowly expanded nationwide thanks to itineraries of proselytization and a popular new television programme. This group strove to provide an Islamic response to the changing needs and aspirations of contemporary Ivorian Muslim society: to reconcile Islam and Ivorian-style modernity. As a young Muslim student put it, Islam then became less of a religion of 'old Dioula traders' and more that of 'young educated executives'. ${ }^{5}$ For convenience, I refer to the imams and Muslim intellectuals of this Ivorian islah (Arabic for reform or renewal ${ }^{6}$ ) as 'moderate revivalists' in a generic fashion (after Kane 2007). ${ }^{7}$

This elite group, which was concerned with the fragmentation and divisions of local Muslim communities and their marginality in the Ivorian nation state, initiated a gradual process of communal restructuring at the national level. This process culminated in the creation of the twin landmark institutions of the Conseil supérieur des imams (COSIM, 1991) and the Conseil national islamique (CNI, 1993). In their early years, COSIM and CNI attracted widespread enthusiasm and support from the Muslim population at large. COSIM and CNI came to represent a church-like superstructure for Islam at the national level, setting out the (supposedly) consensual voice of public Islam in Côte d'Ivoire, in the way that the episcopal conference publicly speaks in the name of Ivorian Catholics (Miran 2006a).

As Muslim revivalists established new superstructures, intellectual endeavours were mobilized to reposition Muslims within the Ivorian past and present. Revivalists in Côte d'Ivoire developed their own keen sense of history; their vision emphasizes Muslims' decisive role in the building and strengthening of

\footnotetext{
' 'Universitaires et cadres, nouveaux imams de Côte d'Ivoire', Le Monde, 15 April 1995.

${ }^{6}$ On islah in sub-Saharan Africa, see Loimeier (2003).

${ }^{7}$ It should be noted that these elites do not use the idiom 'revivalists', but simply call themselves 'Muslim'.
} 
the Ivorian multi-ethnic nation and the republican state. Such memorial narratives came about, in part, as a defensive response against the agonistic ivoirite discourses of the 1990s that reduced Muslims to national insignificance or nuisance. They took place within a global Western-centred mediascape prone to Islamophobia, which Aboubacar Samassi, an influential imam of the 'Riviera 3' mosque in Abidjan, characterized as a pervasive context of 'cultural adversity'. ${ }^{8}$ But this counter-hegemonic historiography also had a more positive side in that it led to Muslims reflecting on and reasserting their engagement vis-à-vis the nation state, both in principle and in practice.

In their effort to align Islam as closely as possible to the backbone of the plural Ivorian nation state, moderate revivalists displayed a blend of patriotism and cosmopolitanism. I borrow the concept of 'patriotic cosmopolitanism' from the African-born, American-based philosopher Kwame Anthony Appiah (1997). Appiah argues that a 'rooted cosmopolitanism' (as opposed to a rootless cosmopolitanism) - or, alternatively phrased, a 'cosmopolitan patriotism' - is not an oxymoron but a real possibility. His father, Joe Appiah, a renowned Ghanaian politician, nurtured multiple, overlapping loyalties throughout his life, from his Ashanti ties to his love for Ghana. A devout Christian, he also urged his children to be citizens of the world, concerned with the well-being of others beyond those in whichever place they chose to live. In a case study on a 'big man' in Botswana, Richard Werbner followed suit with 'rooted public cosmopolitanism'. Appiah's argument, Werbner explains, strikes a liberal middle way between two extreme doctrinal positions - the universalist and the pluralist - or, in the words of the French philosopher Pascal Bruckner, 'between two complementary stereotypes: that of abstract universalism, according to which all men imagine themselves identical; and that of sterile particularism intending to confine each one in the ghetto of her roots' (Bruckner 1986: 117). Similarly, the French Martinican poet and politician Aimé Césaire wrote:

I am not burying myself in a narrow particularism. But neither do I want to lose myself in an emaciated universalism. There are two ways to lose oneself: walled segregation in the particular or dilution in the 'universal.' My conception of the universal is that of a universal enriched by all that is particular, a universal enriched by every particular: the deepening and coexistence of all particulars. ${ }^{9}$

For Werbner, public cosmopolitanism has to do with 'the construction, reconstruction and transcending of difference' (R. Werbner 2008: 180; see also P. Werbner 2008).

In Côte d'Ivoire, Southern autochthons displayed a type of nationalism prone to closure, exclusion and xenophobia. Muslim revivalists' patriotism - a sentiment rather than an ideology - expressed a more open, inclusive and xenophile attachment to the nation. Islam acclaims the umma, the global transnational community

\footnotetext{
${ }^{8}$ Audiotape of Aboubacar Samassi's conference entitled 'Islam et adversité culturelle', n.d. (bought in Abidjan in 1996).

${ }^{9}$ Aimé Césaire, Député (MP) for Martinique, resignation letter to Maurice Thorez, General Secretary of the French Communist Party, 24 October 1956 (translated by Chike Jeffers).
} 
of the Muslim faithful, but Ivorian Muslims found a way to reconcile this with an attachment to the nation. Cheikh Aboubacar Fofana, COSIM's president and 'cheikh (master) of imams' since 2006, referred to the apocryphal Hadith quoted at the start of this article to defend the view that love of one's country (watan in Arabic) is an article of faith.

In the construction of the COSIM-CNI historiography that these revivalists espoused, narratives of cosmopolitan patriotism were eminently subjective and prescriptive. ${ }^{10}$ They spoke of Muslims' desired place in the imagined community that is the Ivorian nation in-the-making, smoothing the rough edges of lived realities and overriding painful episodes. ${ }^{11}$ Genuine efforts at reconstructing the past and making sense of the present were thus entangled in the politics of memory. ${ }^{12}$ Although I point to some silences and simplifications, my focus in exploring this reconstruction is on contemporary re-readings of the past by members of this group, rather than on historical analysis.

\section{Seeing the precolonial past through rose-tinted glasses}

Muslim intellectuals in Côte d'Ivoire proudly recall that Islam was the first monotheistic faith and universal civilization to make its way into Ivorian territory, well before Christianity, which arrived in 1895 shortly after the establishment of the French colony. Islam's ancient presence - evidenced by centuries-old mosques dotting the Ivorian savannah (with ever earlier dates found regularly) - is put forward as consubstantial with its long-acquired indigenous character. Contrary to the view that Islam is a religion of the sword, ${ }^{13}$ Muslim elites emphasize that its introduction and local progress were the peaceful works of Mande traders and holy men. This may also be read as a surreptitious reminder that the early fortunes of Roman Catholic Christianity in Côte d'Ivoire were tied to colonial wars and non-African missionaries. That Islam is a religion of peace, and that it devalues violence, is the foremost leitmotif of moderate revivalists these days and their main explanation for the absence of an Islamic counterpart of ivoirité violence. ${ }^{14}$ Their outrage was unanimous when Muhammad's spiritual message was portrayed as a terrorist ideology before and after September 2001 and during the bloody Ivorian conflicts of 2002-11.

\footnotetext{
${ }^{10}$ Note that Ivorian revivalists do not use the idiom 'cosmopolitan patriotism', but their discourses are replete with variations on their love for Côte d'Ivoire and their fraternal commitment to fellow West Africans or fundamental human values.

${ }^{11}$ Nativist discourses on autochthon history and inter-Southern solidarity also tended to display selective amnesia and some distortion of the facts.

${ }^{12}$ For a serious example of these new historical productions, see the book by archaeologist Lemassou Fofana bearing the evocative title Côte d'Ivoire: Islam et sociétés. Contribution des musulmans à l'édification de la nation ivoirienne (XIe-XXe siècles) (Fofana 2007).

${ }^{13}$ This view has long permeated Ivorian textbooks. In 2001, the history examinations for candidates for posts as inspectors in the primary school system still had to elaborate on the "nonreligious content of Islam which today make it a combat instrument for followers of this religion' (Le Patriote, 24 August 2001).

${ }^{14}$ After the October 2000 post-electoral brutalities and the discovery of a mass grave containing fifty-seven bodies of Dioula young men, imam Aboubacar Fofana stated: 'We [Muslims] are not weak, we are thoughtful. Nobody has a monopoly on violence. But our religion teaches us something else' (Le Patriote, 27 November 2000).
} 
Muslims are said to have reached an accommodation with non-Muslim precolonial societies and chiefdoms, enforcing the distinction between religion and politics in accordance with the scholarly West African Suwari tradition (Launay 1996). Although not without foundation considering Muslims' mercantile pragmatism, this minimizes a Muslim West African military tradition, which contributed to local wars and jihads in the eighteenth and nineteenth centuries. The controversial Almamy Samori Toure is certainly no local hero, as Shehu Usman dan Fodio is in Northern Nigeria. Interestingly, the COSIM-CNI leadership now presents this accommodation with infidel rule as a kind of laïcité before the concept was introduced by Europeans (Miran-Guyon 2014). The local reformist interpretation of Islam is clearly poles apart from a religion of state conquest. Ivorian revivalists have never even claimed public recognition of sharia laws. Muslim personal status laws, it is argued, can be applied solely in the private sphere of the family and community (Ba 2000). They claim that Islam actually strengthens the Ivorian Republic's fundamental laïcité law, even against Christian infringements.

The celebration of Côte d'Ivoire's distant Islamic past is used to counter diverse degrading prejudices. Countering Akan myths and related views that members of the Dioula trader diaspora are unfit to rule (Memel-Fôté 1999), Muslim elites recall that their society is heir to some of the region's greatest empires and has, in Dembélé's words, 'a tradition of imperial and cultural power over the whole sub-region' (Dembélé 2002: 37). Such traditions are, however, just as invented as the Akan myths. Against the stereotype of Islam as a religion of regressive, unrefined illiterates (illiterate in French, that is), revivalists note that Côte d'Ivoire's first schools were in fact Qur'anic schools. Kong - destroyed by Samori in 1897 - Bondoukou, Odienné, Séguéla and Touba were vibrant and influential university towns. According to COSIM, 'Muslims were then among the region's only men of letters, as were rich merchants with sophisticated ways' (COSIM 2007). At one extreme, this feeling of self-importance translated into popular and chauvinist Dioula language through the pejorative labels 'busumani' (bushmen) and kungokônômôgôw (literally bush people), both of which were meant to characterize Southern natives as uncouth peasants and short-sighted savages. ${ }^{15}$

\section{The colonial interlude: times of sorrow, sweat and struggle}

The colonial period is depicted as Islam's darkest hour. With much oversimplification (cf. Triaud 1974), Muslims are portrayed as resistant fighters, while the French colonial state, in collusion with Christian missionaries, is depicted as bent on controlling or repressing Muslim clerics and teachers. This purportedly resulted from 'Islam's fierce opposition against attempts at cultural integration and colonial depersonalization'. ${ }^{16}$ This would also explain why Muslim Dioula

\footnotetext{
${ }^{15}$ In Kourouma's sarcastic novel Monnè, Northerners depict natives of the Ivorian forest as ‘d] es nègres cafres appelés “boussmen"” (Kourouma 1990: 80). The South is sometimes referred to as 'busumani zone'.

${ }^{16}$ Archives of the Communauté musulmane de la Riviera (CMR): audiotape of Mouhamed Kamara's conference 'L'Islam en Côte d'Ivoire', Séminaire international de formation des responsables d'associations musulmanes (SIFRAM), Abidjan/Yopougon, 1994.
} 
flocked in support of the nationalist movement, eliciting the ire of the Catholic Church, according to which Félix Houphouët-Boigny's Parti démocratique de Côte d'Ivoire-Rassemblement démocratique africain (PDCI-RDA) was a party of communists and Muslims. The Church's attitude notwithstanding, the reality was far more nuanced and had less to do with religion per se and more to do with pragmatic arrangements (Person 1982; Miran 2006a: 136-9). Be that as it may, Muslims from all walks of life are proud to have been among the first to back Houphouët's political activities, as exemplified by Houphouët's alliances with the Hamawi Yacouba Sylla (Hanretta 2009) or with Gbon Coulibaly of Korhogo (Launay 1992; 1997). According to imam Aboubacar Fofana:

Ever since Côte d'Ivoire exists ... [the Muslim] community has played an important role in the unity of this country, the role of balance. At one point, this community rejected the candidacy of a brother in order to accept the candidacy of someone who was neither a Northerner, nor a Dioula, nor a Malinké, nor a Muslim ... One really cannot say that this community was sectarian, whether through Islam's teaching or by its history. ${ }^{17}$

Revivalists recall that Muslims celebrated independence as a recovery of freedom even more than other communities did. Although revivalist intellectuals harshly criticized the disappointing continuation of colonial-period Islamic policies into the new age of national sovereignty, Muslims at large kept their strong attachment to President Houphouët until his death. This state of affairs is presented as proof of Muslims' durable civic engagement, and their setting of public and national interests over those of their community.

Although the narratives of Muslim elites fail to acknowledge the fact that the colonial situation itself introduced geo-demographic changes conducive to Islam (Triaud forthcoming), they strongly emphasize the contribution of Muslim strangers to the making of the new colonial and postcolonial Ivorian South. Muslims/Dioula present themselves as second arrivals in each and every region of the forest and coastal zones. They similarly present themselves as the sole group that is established in the four corners of the country, alluding to a Muslim appropriation of the South and a Muslim promotion of trans-local, national unity by means of concrete practices, in contrast to groups that are claimed to have had a narrower, village-based vision of a collective destiny. Northerners recall that they moved southwards for trade and other economic reasons. They cherished social peace and wanted to be on good terms with their hosts. All the while, they worked hard and played a key role in the success of the plantation system and in the later Ivorian 'miracle'. It is argued over and over again that Côte d'Ivoire would not have enjoyed the same economic fortunes without the inputs of Voltaic/Burkinabè and other foreign workers (Fofana 2007: 69-78; over two-thirds of Burkinabè living in Côte d'Ivoire are Muslim). ${ }^{18}$ In particular, Muslims pride themselves on having built and peopled all the Southern

\footnotetext{
${ }^{17}$ Archives of the Association des jeunes musulmans de Côte d'Ivoire (AJMCI): audiotape of Aboubacar Fofana's conference entitled 'Contribution de l'Islam à l'unité nationale', Ibis Hotel, Plateau/Abidjan, 31 December 1995.

${ }^{18}$ In Venance Konan's caustic novels, south-western native villagers call their unskilled Burkinabè workers 'Catapila' because they are as good as Caterpillar tractors for clearing the land (Konan 2005; 2009).
} 
towns: dioulabougou ${ }^{19}$ mosques and Islamic schools now dot the Southern forest as much as the Northern savannah. This also applies to Muslim cemeteries, as Islam requires the immediate burial of the deceased on the very site where death occurred. (In contrast, most of the societies in Southern Côte d'Ivoire bury their dead in their native village or that of their ancestors, even if the death occurred far away from the village.) In reply to the claims of Southern natives that Northerners did little to build and develop their own Northern villages, Muslim/Dioula reply that they have a different and less parochial relationship to the land, and that they built and developed the neighbourhoods and regions where they settled, which then became new homes. ${ }^{20}$ Abidjan, Bouake and Daloa were gradually made into intellectual Islamic centres in their own right.

These diffuse analyses concerning the significance of the Dioula/Muslim contribution to the country's twentieth-century history are endorsed by Robert Launay. He views the formation of the Dioula community in the colonial South as more than merely the product of in-migration: it resulted from major, internal postmigration changes involving, most importantly, Islamization processes associated with a greater standardization of religious practices. These processes in turn led to the intertwined formation of 'Dioula Islam'. Launay argues that:

the formation of the Dioula community was, along with the development of plantation agriculture, at the very heart of the creation of the modern political economy of southern Côte d'Ivoire, if not of the country as a whole. The fact that Islam is the religion of roughly half the population of Côte d'Ivoire is directly the result of the development of the Dioula community and indeed of 'Dioula Islam'. (Launay 2005; see also Launay 2012)

Such arguments clearly contrast with pro-ivoirité historiography, but also subtly criticize older academic approaches to the Ivorian past, which tended to relegate Islam to a kind of built-in subalternity, rendering the eventuality of Muslim agency in co-writing national history barely imaginable.

\section{Good Muslims, good citizens}

The revivalist leadership iterates Muslims' hearty embrace of the promises of independence and their endeavours to be good citizens as well as good Muslims. It claims that Dioula have been generous hosts to late migrants, including Southern natives moving to towns and, later, children assigned to state schools far from their homes. ${ }^{21}$ Dioula men have married into all ethnic groups (Dioula women far less so). Dioula, the language of the marketplace, became a national lingua franca along with French and was the only vernacular in which Bété and Baoulé were

\footnotetext{
${ }^{19}$ Dioulabougou is a generic equivalent of the Hausa zongo: strangers' enclaves or neighbourhoods in post-migration towns.

${ }^{20} \mathrm{As}$ McGovern underlined, Mande forms of identity have little to do with relations to ancestral land and are linked more to membership in named jamuw or clans (McGovern 2011: 52).

${ }^{21}$ For a long time, the state assigned pupils to middle and high schools regardless of familial residence. Urban Dioula extended families often served as tuteurs (hosts/guardians) to these 'uprooted' children, providing free lodging and food across the ethnic, regional and religious spectrum. Laurent Gbagbo benefited from such hospitality in the family of Cheikh Yacouba Sylla in Gagnoa.
} 
able to communicate with one another. ${ }^{22}$ Above all, Muslim intellectuals recall how Islam spread steadily and peacefully throughout the South, first among strangers and later among members of Southern lineages as well (Miran-Guyon 2012), thus becoming a true cosmopolitan-cum-national religion. Although revivalists discreetly contest statistics they believe to underestimate the Muslim population, they feel deeply gratified that even these figures recognize that Islam has become the first religion of the country. In 1995, at the dawn of ivoirite politics, COSIM's spokesperson advanced the view that ' $[\mathrm{t}]$ he unity of Côte d'Ivoire cannot be conceivable without the Muslim community, which it has to be said represents an important segment of Ivorian society'. ${ }^{23}$ Conversely, it was agreed that Muslims alone could not ensure the country's unity nor its social peace, understood to be a joint endeavour involving other communities 'from below' as well as the state 'from above'. ${ }^{24}$

Muslim patriotic sentiments were expressed in a pragmatic yet candid fashion in 1974 by Guinean Wahhabis from Séguéla, petitioning Houphouët for authorization to build their own neighbourhood mosque.

Although of Guinean origins [they wrote] we consider ourselves Ivorians for most of us were born in Côte d'Ivoire and have more than thirty years' existence [i.e. residence] during which we spared no effort for the common interest of this Ivorian nation of which we are children. We have no other homeland [patrie] outside Côte d'Ivoire, where we have all our interests, buildings, plantations and businesses. ${ }^{25}$

In the same vein, in the troubled early 2000s, Aboubacar Fofana affirmed that Muslims are "the community which loves this country more than all other communities because [they] invested in it throughout and buried [their] parents in every place'. ${ }^{26}$ There is anecdotal evidence that this patriotic love had again been expressed in 1973 when a Muslim MP was the first to propose, upon his return from the pilgrimage to Mecca, that the translation of the country's name into foreign languages should be barred by law. The French 'Côte d'Ivoire' being unfamiliar abroad, Ivorian pilgrims deplored the difficulties in having their national origin identified. Sékou Diakité made it a matter of national honour for the country to have its proper, inalienable name. ${ }^{27}$ The law was voted in ten years later.

Cognisant of a certain Muslim 'backwardness' vis-à-vis Western-educated segments of Ivorian society, and the Catholic community in particular, 1970s Muslim

\footnotetext{
${ }^{22}$ According to an official source, approximately 65 per cent of Ivorian residents speak Dioula (dioula tagbusi) as a first or second language: that is, more than speak the official French (N'Goran-Poame 2007: 87). Dioula also served as the substrate language in the formation of various slangs such as nouchi, a popular neo-creole that also borrows from the French and other Ivorian vernaculars.

${ }^{23}$ Archives of AJMCI: audiotape of Aboubacar Fofana's conference on 'Islam and Nationbuilding in Côte d'Ivoire', Ibis Hotel, Plateau/Abidjan, 31 December 1995.

${ }^{24}$ As Aboubacar Samassi remarked at the close of Aboubacar Fofana's 1995 conference.

${ }^{25}$ Republic of Côte d'Ivoire, archives of the Interior Ministry, Wahhabiyya file: letter addressed by the Guinean residents of Séguéla to President Houphouët-Boigny, 13 December 1974.

${ }^{26}$ 'Imam Aboubacar Fofana. Réconciliation nationale: "Une réconciliation sans justice ne serait qu'une grosse farce!’', Plume Libre, 11-17 May 2001.

${ }^{27}$ Personal archives of Hajj Boubacar Sakho in Treichville: Sékou Diakité's report on the $1972-$ 73 pilgrimage to Mecca.
} 
students of the Association des élèves et étudiants musulmans de Côte d'Ivoire (AEEMCI) were the first to enunciate what they called 'a modern Islam' (Touré 2008: 16; Miran 2006a; 2006b), in which the language was French and the discursive mode was rational. Since then, a prime leitmotif of revivalist rhetoric has been that Muslim men and women of good morality and good social behaviour are de facto good citizens, translating their religious qualities into civic qualities in relation to their fellow countrymen and the public authorities. (The reality is never that simple, of course, but then not all Muslims are good Muslims.) As COSIM imams explained, fundamental values of Islam - honesty, respect, responsibility, self-discipline, solidarity, and so on - are not fundamentally different from the core values of the democratic, secular republic. The Qur'an leaves it to humankind to decide what political regime best fits the needs of the Muslim community. As long as the Ivorian Republic adheres to its own values and principles, the imams explained, its Muslim constituency will be counted among its most loyal supporters. 28

Conversely, it is said that responsibility also falls on Muslims to warn their fellow countrymen and public authorities against injustice, for, as the Hadith metaphor goes, when a boat sinks, all the passengers, good or bad, eventually drown (Sahih Bukhari 683). Imam Fofana, then COSIM's spokesperson, formulated such a public warning when he declared in front of the putschist President Robert Gueï in June 2000 that 'Côte d'Ivoire cannot be the country of a single region, it cannot be the country of a single ethnic group, it cannot be the country of a single religion. It is a Republic, it is secular, it is multidimensional, it is multi-religious, it is multi-ethnic. This has to be recognized. ${ }^{29}$ COSIMCNI fiercely contested nativist frontiers of inclusion and exclusion in the public sphere and demanded the recognition of legally based citizenship (as opposed to ethno-territorially based citizenship), along with equal participation in national debates.

In sum, revivalist narratives drive home the idea that Islamic society and religious culture in Côte d'Ivoire were always geared towards societal consolidation and political integration. They did not express exclusionary or conflictual themes in the jihad modes of exit-option or confrontation. Muslim intellectuals emphasize that Islam in Côte d'Ivoire is no foreign religion, no turnkey import from the Arab Islamic world. If the COSIM-CNI leadership questions traditional customs that depart from the Qur'an and Sunna, it also makes it clear that it aims to rethink Islam's everlasting dogmatic principles as mirrored in the ever-changing Ivorian context. In other words, it aims to reaffirm Islam's relevance at all times and in all places by demonstrating its relevance here and now within the plural, modern and now globalizing Ivorian society. According to this view, Islam's normative cosmopolitanism should be rooted in patriotic and vernacular loyalties and understandings.

\footnotetext{
${ }^{28}$ Interviews with Ousmane Diakité, COSIM national secretary, 23 December 2007, and Aboubacar Fofana, 5 January 2008.

${ }^{29}$ This discourse, perceived by many as courageous given the circumstances of the time, is by far Fofana's best known public statement to date. Reproduced in full in Les Cahiers du CEID 1 (August 2000): 18-19.
} 


\section{XENOPHOBIC MUSLIMS? ETHNO-NATIONALIST CLEAVAGES FROM WITHIN}

As a discursive construct, the Muslim cosmopolitan patriotism presented above was clearly the product of an intellectual elite. It coalesced in the 1990s and was new in that it tackled the country's previously unacknowledged Muslim past and ultimately (re)claimed the right of Muslims to co-write the Ivorian present alongside their fellow citizens. Despite this, it was more than a mere invented tradition. After all, revivalists' descriptions of, for example, Muslim-'animist' peaceful relations in the precolonial North, or Dioula hospitality to Muslim and non-Muslim schoolchildren and late migrants in the South, were genuine realities rather than fabrications. The celebratory cosmopolitan patriotism of the elites thus echoed that of migrants. Both entailed a bricolage of elements gleaned from the space between the local and the global: both embodied Muslim/Dioula 'everyday cosmopolitanism', defined as 'the ways in which the ordinary members of different ethno-religious and cultural groupings mix, mingle, intensely interact, and share in values and practices - the cultures of food, fashion, language, and symbols - in history and memory' (Bayat 2008; see also examples in Miran 2006a). This explains why rank-and-file Muslims, though not always as sophisticated as elite discourses imply, largely sided with the revivalist leadership to defend these views in the public arena, and this trend plainly grew as the ivoirité clashes spread.

Shifting from discourse analysis to detailed description, this second part of the article questions anew the aspects that were consigned to oblivion by this publicrooted cosmopolitanism in order to support its vision; it focuses on those "bestforgotten' episodes that fit poorly into the patriotic-cum-cosmopolitan imaginary. In retrospect, these do not delegitimize this imaginary altogether but add critical nuance to both Muslim history and revivalists' politics of memory (a point taken up again in the conclusion).

Muslim cross-ethnic and cross-national fraternity and solidarity were effective sentiments, which often translated into practice. Nonetheless, local lived experiences were never that simple or ideal. Despite their broad language, cultural and religious bonds, Muslims at large - Northern Dioula and foreign migrants in particular - were caught up in intense competition for power and resources, both material and symbolic. This socio-economic competition was usually regulated internally. But occasionally it fuelled tensions and disputes, resulting in atomization and cleavages on diverse grounds, including those of regional and national origin. Although not religious at their core, these factional rivalries extended to the spiritual arena. This section explores how and to what extent the Ivorian Muslim community flirted with the demons of exclusion and xenophobia from within its own ranks.

\section{Diversity within: polyphony and cacophony}

'Dioula' themselves were far from being a single coalesced community even in Northern Côte d'Ivoire (Launay and Miran 2000; LeBlanc 1999; 2000). Not all Northerners, of course, are Mande-speakers, whatever the popular representation in the South. Nor are they all Muslim. Now and again, Malinké/Dioula have been at odds with Gour-speakers such as the Sénoufo, many of whom converted to 
Islam during the colonial era, although not all are Muslim today. Tensions were already rife in the decolonization context of the 1950s. As Aristide Zolberg reported: 'The Sénoufo, Djimini, and Tagouana of the northeast complained that the Malinké of the northwest were continuing the process of conquest begun by Samory and were trying to subject the entire North to their commercial and cultural imperialism' (Zolberg 1964: 203). In a wave of ethno-cultural reawakening starting in the $1980 \mathrm{~s}$, and then as a means to counteract Northerners' political exclusion from the era of ivoirité in the 1990s, many Sénoufo intellectuals and, later, ordinary Sénoufo gave up their adopted Dioula names and re-appropriated 'proper' Sénoufo names (Tuho 1984).

Despite their strong organic ties and networks, Mande-speaking Malinkél Dioula of Northern Côte d'Ivoire did not constitute a united, uniform society either. There were internal differentiations that related to social status (traditional, but now fading, markers of exclusion in marriage and religious privilege): nyamakala (craftsmen or 'casted' people), hôrôn (free or noble men) and jôn (men of servile origins). In addition, Dioula 'ethnic' identity was territorialized. Dioula originating from different regions or towns of the Ivorian savannah were mutual 'strangers'. Yet, while on the move, they owed each other reciprocal hospitality as 'host' and 'landlord' or diatigui (Launay 1979; Gary Tounkara 2008). In Lemassou Fofana's words:

Etymologically, the diatigui designates the autochthon, the one who has always been there and who receives a newcomer. In commercial terminology, the diatigui is the one who knows the region well in terms of commercial realities and is thus able to provide useful information on the seasons, harvests, raw materials price, and commercial routes. (Fofana 2007: 35)

Islam fostered the duty of fraternal solidarity but privileges were otherwise restricted, as alluded to in 1975 by the imam of Korhogo. At that time, a new group of Wahhabi or Sunni Muslims wanted to build their own, separate, Friday mosque in town. Although doctrinal issues were in the background, the stakes of the imam's opposition lay elsewhere. '[T]he Sunnite mosque will not be built here in Korhogo,' the imam made clear, 'because Korhogo belongs to the citizens of this city, and it is not for strangers. But the mosque can be built in Bouaké, because it is a town where strangers have met, like Abidjan, but Korhogo is not that kind of town' (Labazée 1993: 137). Such remarks were dissonant with the vision of rooted cosmopolitanism.

Ivorian Malinké brought their distinctive regional identities with them when they settled in Southern Côte d'Ivoire, as did external migrants coming from further north (LeBlanc 2000; 2003). This local situation produced enduring social and religious fault lines even within the context of an increasingly homogeneous 'Dioula' Muslim community, formed through the gradual assimilation of its cosmopolitan segments. These fault lines were often barely visible, but sometimes publicly exposed.

Dioulabougou mosques incorporated many community elements, socio-political and economic as well as religious. Accordingly, control over the imamate has always been a key community issue. To control competition, tight regulation was established. In the Northern Ivorian hinterland, the imamate was more or less entrenched in the hands of locally distinguished marabout families or mory 
kabla: the Savané family in Odienné; the Diaby in Samatiguila; the Bakayoko in Séguéla; the Fofana in Mankono; the Coulibaly in Korhogo; the Timité in Bondoukou, and so forth. As this model was not readily transferable to the fluid context of migration, the solution generally favoured was to alternate imams according to place of origin (usually a rotation between two major regions); this was carefully monitored by a mixed committee of Dioula elders. Such committees oversaw the appointments of new imams when vacancies occurred due to deaths. Such a socio-religious organization was not only 'completely tribalized', it also tended to 'exclude external migrants'. ${ }^{30}$ While far from xenophobic, it did not demonstrate xenophilia either.

Even so, disagreements among Ivorian Dioula migrants were not uncommon. Most of these conflicts involved the Odiennéka. ${ }^{31}$ Revered for their knowledge of Islamic sciences, their mosque-building initiatives and their organizational skills, they were nevertheless commonly decried as chauvinists and religious imperialists, especially when they refused the appointment of a non-Odiennéka imam. Factional disputes occurred as early as the 1930s in Agboville, Bouaké, Daloa, Dimbokro, Gagnoa, Man and elsewhere. In Gagnoa in 1934, a violent quarrel between Odiennéka and Worodougouka ${ }^{32}$ (or Koyaga) led to the building of a new Worodougouka-led mosque. Thanks to the mediation of the colonial-friendly Senegalese marabout Seydou Nourou Tall, Koyaga later agreed to pray separately only during the week, but to join the Odiennéka for the Friday khutba so as to avoid the curse of fitna or division of the umma (Launay and Miran 2000). In 1965, in the village of Dignago (Guibéroua sub-prefecture), Koyaga became irate at Odiennéka, whose newly appointed imam went as far as to 'declare publicly that the office of imam was their ethnic group's preserve and that they would refuse to concede the slightest morsel of it to whoever was not from Odienné'. ${ }^{33}$ In the end, Dignago's Koyaga not only built their own mosque but also appointed their own neighbourhood chief and formed their own PDCI section.

All this explains why Aboubacar Fofana, the national 'cheikh of imams' (in 2006) and himself an Odiennéka born in Abidjan, has always been proactive in assigning non-Odiennéka to positions of leadership within the revivalist movement, thereby strengthening synergetic impetuses within the pluralistic Muslim community. One of the reasons behind his 1993 choice of the then unknown Koudouss Idriss Koné as CNI's president was that he was a Korhogoka - and a jeli (or griot) at that.

Intra-Muslim conflicts among the Ivorian Dioula were not limited to instances involving the Odiennéka. From the mid-1980s to the early 2000s, Koumassi central mosque in Abidjan was wryly nicknamed 'the Iran-Iraq mosque' because of the prolonged struggles between Sénoufo and Koyaga pretenders to the throne of imam, a war of words occasionally punctuated by punches. Referring to this and to other conflicts, an Ivorian Muslim journalist harshly concluded: 'We [Muslims] have our share of responsibility in the ivoirité

\footnotetext{
${ }^{30}$ Interview with Moussa Touré, 29 May 2009.

${ }^{31}$ The Dioula suffix $-k a$ indicates the place of belonging.

${ }^{32}$ Worodougou is the region around Mankono.

${ }^{33}$ Private archives of Father Gwenolé Jeusset: letter by Dignago residents from the 'cercle de Orodougou' to the 'Centre-Ouest' prefect in Daloa, 28 October 1965.
} 
concept. ${ }^{34}$ Newly appointed imams were mostly peaceful, but such sporadic disputes between Ivorian Dioula of discrete regional origins showcased local xenophobia - 'parochial' xenophobia from within a single state - which revivalists carefully omitted from their discourse.

\section{Being an Ivorian Muslim versus being a foreign Muslim}

Many Dioula tagbusi (Dioula métis or Dioula raised in the Ivorian South and influenced by the mores of Southern natives ${ }^{35}$ ) do not maintain close relations with their ancestral hometowns as did earlier generations. However, their memory of the 'village' was never lost. To a certain extent, it has been revived in recent years by the renewal of Maulid celebrations. Long neglected as hopelessly folkloristic, the Maulid holiday now results in a northwards exodus of Abidjanese and other Southern urban-dwelling Dioula to their home villages, regardless of social class. Maulid gatherings in the Odienné-Samatiguila region and in Yorobodi are particularly attractive. There, the gathered faithful praise not only the Prophet Muhammad but also the virtues of native sons' involvement in local development. Commodities are exchanged and marriages arranged. Thus, the new Maulid festivities to some extent emulate the older, enduring Pâqui-nou (Easter) celebrations, which are popular among Baoulé Catholics, who thereby also renew allegiance to their rediscovered ancestral land. ${ }^{36}$

But the most sensitive example of intra-Muslim divisiveness in Southern Côte d'Ivoire occurred between Dioula of Northern Ivorian origins on the one hand and all foreign, external migrants on the other. This is not to say that disagreements prevailed; rather, there were considerable levels of solidarity, especially in town, if only in a pragmatic semi-indifferent fashion. In San Pedro in the early 1980s, the local Muslim community was made up of seventeen subgroups representing ten Ivorian regions and seven foreign countries. Community life was regulated fairly peacefully via consultations between notables of these seventeen committees. ${ }^{37}$ Regional disparities in 'Ivorian'-'foreign' Muslim relations are not readily subject to broad generalizations; non-religious factors, and matters of chronology, must also be considered. In the early colonial period, before the era of national identities, in times when 'Ivorian' Dioula lacked experienced religious personnel, territorial or 'country' origin was not a religious bone of contention per se. In many towns of the South, and especially in Basse Côte, it was socially acceptable for Senegalese and, to a lesser extent, French Sudanese to monopolize local religious hierarchies. However, it is true that Senegalese (most commonly Wolof) religious egoism was occasionally condemned, a charge shared by

\footnotetext{
${ }^{34}$ Al Fourqane, 29 October 2006, and interview with Ibrahima Touré 'Al Fourqane', 17 July 2009. The Muslim journalist was so angry at this mosque dispute that he categorized it, along with any other kind of exclusionary behaviour, as deriving from ivoirité.

${ }^{35}$ The term tagbusi is pejorative when used by 'traditional' Malinké lamenting the loss of 'proper' Malinké traditions, but less so in the vocabulary of young 'Southern Dioula' and their Southern native peers.

${ }^{36}$ Maulid 'pilgrims' bound for Yorobodi said it clearly: 'It is our Paquinou and it is unthinkable to stay in Abidjan' (Islam Info, 26 March 2009).

${ }^{37}$ Archives of the Ivorian Interior Ministry: report on San Pedro, AMOCI file, 9 September 1983.
} 
most non-Senegalese. Such was the case in 1931 in the Abidjan neighbourhood of Treichville. A local Friday mosque had been built in the late 1920s and was led by Fétigué Konaté, a Mande-speaking imam from Upper Volta. But, in 1931, the Senegalese (mostly Wolof) notables who had been behind the recent building of a second mosque on the same street decided that their edifice should become the neighbourhood's sole Friday mosque. By the time tensions subsided (thanks in part to the Senegalese Seydou Nourou Tall), the divided communities had taken positions in their respective Friday mosques: the 'Dioula' mosque for Mande-speakers, and the 'Wolof' (later the 'Senegalese') mosque for their families. After a second conflict on the premises of the Senegalese mosque in 1939, non-Wolof left for the 'Dioula' mosque and later for Treichville's small, third, 'Peul' mosque (Miran 2006a: 111-12).

After independence, national origin took on a new salience, and could be used as a factor of differentiation or exclusion within the hybrid Muslim community of Côte d'Ivoire. In 1963, in the village of Moussadougou (Lakota sub-prefecture), a group of Malians and Voltaics emphasized their distinctive Hamawi/Yacouba Sylla religious identity and broke away from the rest of the Muslim community. This disturbed Ivorian Muslims, who ended up bringing a complaint before the local authorities. The Malian-Voltaic coalition, they argued, organized 'clandestine meetings during which they say that Côte d'Ivoire wants to send home all foreigners'. The sub-prefect agreed that it was 'intolerable that others come to this hospitable land of Côte d'Ivoire to sow discord when we ask for peace to develop ourselves'. ${ }^{38}$

Even more evocative of this nationalist turn was a third conflict over mosques in Treichville, which came about in 1966 within the confines of the 'Dioula' mosque. Following the death of imam Yaya Cissé of Odienné (who, years earlier, had replaced the deceased Fétigué Konaté from Upper Volta), the Ivorian Dioula opposed the anticipated appointment of his deputy imam, a Voltaic supported by Voltaics, Malians and Guineans. When the Ivorian faction managed to impose a new Odiennéka imam, the foreign faithful left en masse for the Senegalese mosque. The latter then became known as the 'foreigners' mosque', while the Dioula mosque was called the 'Ivorian mosque'. The dispute's 'nationalist' overtones masked other fundamental socio-economic cleavages, and, at the same time, it was a convenient way to marginalize competitors. It is telling that some Ivorian Muslims mimicked the nationalist, even xenophobic, rhetoric that pervaded Ivorian society at the time. Commenting upon the three Treichville disputes, Hajj Boubacar Sakho, a local resident and influential Malian dignitary, wrote: 'political decolonization opened up a religious decolonization via the elimination of all non-autochthon elements'; 'Ivorians should consider muzzling the tribal and religious demon by refraining from evoking divisive factors between foreigners and Ivorians, for Islam in Côte d'Ivoire owes a lot to foreigners'. ${ }^{39}$ Nonetheless, countless complaints kept coming from foreign Muslim communities about their Ivorian co-religionists. What foreigners typically alleged was that they bought plots and built small neighbourhood mosques and then, when everything

\footnotetext{
${ }^{38}$ Archives of the Ivorian Interior Ministry: letter from Lakota sub-prefect, 5 January 1970.

${ }^{39}$ Private archives of Hajj Boubacar Sakho: non-dated manuscript entitled Les conflits dans la communauté musulmane d'Abidjan de 1931 à 1966.
} 
was in place, Ivorians claimed the imamship. ${ }^{40}$ In 2009, Cheikh Aboubacar Fofana had to resolve a long-standing mosque dispute in Soubré between Burkinabè and Ivorian Muslims. He vehemently urged the local faithful 'not to fall back into the identity complex' verging on 'racism'. ${ }^{41}$

Even when local communities showed no tension, the nationality factor still affected the spiritual geography of Southern towns. This was the case in the Abidjan neighbourhood of Adjamé, where two mosques were located back to back: the older 'Mairie 1' mosque, also called the 'Sudanese' or 'foreigners' mosque', which had always been led by a Malian imam; and the newer 'Ivorian' mosque built in the late 1950s, with the latter becoming the neighbourhood's central mosque until the late 1980s thanks to Houphouët's subsidies. It also became the country's prime monumental Islamic edifice, and was the mosque usually attended by government office holders for jumah prayers and holidays. In the North and in Abidjan and Southern dioulabougou, non-Ivorian strangers could supervise their own neighbourhood mosques where they spoke their own vernacular languages, but not a central mosque with public visibility. Echoing the processes at play in the central administration and in the Christian clergy, the imamate thus underwent a sort of Ivorization. For decades, Ivorian and foreign Muslims commonly celebrated Islamic holidays on different days, as foreigners aligned themselves with the dates set by their countries of origin. Nothing upset the new generation of revivalists more than this cacophony, since Eid holidays, which were supposed to celebrate the unity of the umma and to promote mass prayers in urban public spaces, became unintended demonstrations of the community's internal divisions.

\section{When sectarian preference meets national difference}

The so-called 'Wahhabi' versus 'traditionalist' disputes of the mid-1970s and early 1980 s were further testimony to the ways in which nationality fault lines could produce internal schisms. It goes without saying that these disputes were first and foremost based on differences of doctrinal interpretation that had major social and generational implications. Yet, within limits, sectarian issues also reflected nationality cleavages in that a significant proportion of Wahhabi (also 'orthodox', later 'Sunni') spokespersons and followers were non-citizen foreigners, mostly Guineans and, to a lesser extent, Malians. Wahhabis first appeared in the 1950s, and when they resurfaced in the postcolonial public sphere they defended their right - fiercely contested by the majority traditionalist Ivorian/ Dioula Muslim society - to build their own mosques and manage their own community affairs separately. This religious activism may thus be cautiously read as a hidden transcript for disenfranchised and marginalized foreign nationals reclaiming the right to supervise their own post-migration destiny in Côte d'Ivoire. ${ }^{42}$

In 1981, matters became more complicated when an intricate dispute erupted violently within the ranks of the Wahhabi community. Although this cannot be

\footnotetext{
${ }^{40}$ Interview with Oumar Ba, 28 July 2009.

41 'Soubré: Boikary Fofana déconseille la politique dans les mosquées', Nord Sud, 30 July 2009.

${ }^{42} \mathrm{On}$ the minority participation of Southern native converts in the Wahhabiyya, see MiranGuyon (2012).
} 
reduced to matters of xenophobia and cosmopolitan ideals, it is clear that one faction came to the defence of foreigners against Ivorian/Dioula 'racism' while the other emphasized patriotic pride. All parties coveted the Wahhabi central mosque in Abidjan. The foreigner-friendly faction 'list[ed] fifty mosques in Côte d'Ivoire ... led by Ivorian imams, most of whom came from Odienné, and ask[ed] the President of the Republic to intervene to allow them to lead the only mosque which they ha[d] built in Abidjan'. For the Ivorian faction, these remarks were 'an insult to our country'. ${ }^{43}$ 'If one of the prime concerns of our beloved Head of State,' the Ivorian party continued, 'is that the Ivorian give hugs to foreign nationals, on the other hand, he does not turn down reciprocity of feelings between Ivorians and non-Ivorians. ${ }^{44}$ It so happened that the imam whose dismissal initially triggered the 1981 conflict was a Malian. This had not caused problems in 1976 when he had first been appointed, but the Ivorian faction later argued that 'in principle, the imamate should be entrusted to an autochthon and not a foreigner'. ${ }^{45}$ The conflict dragged on for years, without leading to a clear solution (details in Miran 2006a).

Just like the Wahhabiyya and Hamawiyya mentioned previously, the Ahmadiyya minority and one particular Shi'a movement distinctively served as platforms of initiative and empowerment for many West African foreign migrants facing Ivorian censure, at least until the mid- to late 1980s (Yacoob 1980; Miran 2002). It would be misleading to conclude from this fragmented data that the 'autochthon'/'foreign' cleavage best encapsulates the complex tensions that have long been at play within the plural Muslim society of postcolonial Côte d'Ivoire. But one can also clearly conclude that nationality-based tensions affected the Muslim community from within. Muslim latecomers from all walks of life, living in the non-Muslim and sometimes hostile environment of the Ivorian South, generally fostered solidarity to face shared challenges. But this solidarity was not always sufficient to mitigate abiding competition. The existence of these fault lines, needless to say, was at odds with the rhetoric of patriotic cosmopolitanism.

\section{CONCLUSION: RECONCILING THE INDIGENOUS WITH THE COSMOPOLITAN}

Revivalist elites have always emphasized the distinction between Islam and Dioula ethnicity and nationality, their primary intent being to counteract the protean inclinations towards divisiveness among local Muslims. Preaching consistently emphasized that fitna and blatant disunity were not only outrageous in view of Islam's universal principles, but also debilitating from a socio-political standpoint. This said, COSIM-CNI representatives made great efforts to respect the

\footnotetext{
${ }^{43}$ Archives of the Ivorian Interior Ministry: Gaoussou Diabaté's letter to the Interior Minister, 8 June 1981.

${ }^{44}$ Archives of the Ivorian Interior Ministry: Gaoussou Diabatés letter to the Interior Minister, 6 May 1983.

${ }^{45}$ Archives of the Ivorian Interior Ministry: minutes of a meeting between conflicting factions at the Interior Ministry, 8 July 1981.
} 
community's basic sociological balance - as with the curbing of Odiennéka dominance - so as not to provoke another generational or doctrinal schism. In 1993, Koudouss Idriss Koné insisted at the launch of the CNI that the new Islamic federation was 'neither a matter of foreigners nor of Odiennéka, Mahouka, Koyaka, or Sénoufo' but 'the emanation of all the country's Muslims'. ${ }^{46}$ 'What matters most,' summarized Aboubacar Fofana in 1995, 'it is what we do, not where we come from. ${ }^{47}$

The islah-oriented discourse did not take place in a sociological vacuum. It was carried by new, growing generations of urban Western-educated francophone or Arab-speaking Muslims, who moved out of the dioulabougou to mixed residential areas and found employment in the formal sector. This discourse of Islamic reawakening also developed in an effervescent religious landscape, a context that accounts for the progress of the Qur'anic prophecy, noticeably among ethnic groups that had previously been impervious or even hostile to Islam. It was during this period that Islam became the country's first religion from a demographic standpoint. Similarly, the anti-discrimination posture of COSIM-CNI was developed in the political context of ivoirite and Southerners' ultranationalist nativism. In return, the troubled political environment of the 1990s and 2000s reinforced the revivalist movement's appeal at the popular level. Working in Bouaké in the 1990s, Marie Nathalie LeBlanc explored the phenomenon among Muslim youth of Malian origin. She argued that their re-Islamization was - in part, at least - a consequence of the political (dis)order of the time. The adoption of a standardized ('Arabized') Islamic identity of a substantive or political order - as opposed to the ethnic ('sya') and customary identities of an existential or habitual order - was a way out of President Bédié's exclusionary politics. Young Malians were loosening the bonds with their country of origin and binding their destiny to Ivorian or Dioula Muslims (LeBlanc 1999; 2000).

The accretion of these varied factors and circumstances led to the slow but unmistakeable rise of the revivalist movement. This in turn explains why the new public rhetoric on Islam has succeeded in having such a decisive impact on Ivorian Muslim society. Mosques, especially newly built mosques, are no longer named after ethnic or national groups; Arabic or Islamic names now prevail. In the early 1990s, reform-minded preachers approached the elders of the Treichville Dioula mosque, which had been attended mostly by Ivorian nationals ever since the 1966 conflict. In 1993, when a thorough restructuring of the mosque's management was agreed upon, representatives of the local Burkinabè, Guinean, Malian, Nigerian, Nigerien and Senegalese communities were invited to participate. Ever since, the mosque has been open to all Muslims, whatever their origin. It was also chosen as the headquarters of the COSIM national secretariat. ${ }^{48}$

A still-unreleased imamate charter has spelled out that non-Islamic criteria such as genealogy, ethnicity and nationality ought not to be relevant in the choice of

\footnotetext{
${ }^{46}$ 'Conseil National Islamique. El Hadj Drissa Koné, nouveau président', Fraternité Matin, 11 January 1993.

${ }^{47}$ Archives of AJMCI: audiotape of Fofana's conference on 'Islam and Nation-building in Côte d'Ivoire', Ibis Hotel, Plateau/Abidjan, 31 December 1995.

${ }^{48}$ Interview with Oumarou Diabaté, 26 August 1996.
} 
spiritual guides. The enduring sensitivity of the matter, however, has long delayed its publication; older, traditionalist, Dioula imams fear being replaced by enterprising and better-educated young men. Such was especially the case in Northern Côte d'Ivoire, in Southern dioulabougou, and in the popular quarters of Abidjan. Nonetheless, wherever there is a concentration of reform-minded Muslims, as in the Cocody district of Abidjan or in the many provincial towns housing Muslim civil servants and professionals, precedence has been given to religious knowledge and personal merit over traditional considerations. ${ }^{49}$

The cosmopolitan character of the revivalist community itself has been more a strength than a disadvantage. Its three leading intellectuals were the Ivorian Aboubacar Fofana, the Malian Tidjane Ba (a Tijani who later became Ivorian), and the Guinean Mohammed Lamine Kaba (a Wahhabi). In principle, at least, foreigners were as likely as Ivorian citizens to be promoted as presidents of Islamic associations. In practice, since Ivorian legislation requires associative office holders to be Ivorian nationals, foreign Muslim members first had to undergo naturalization in order to become eligible. Such was the journey of Nurudine Oyewolé: born Nigerian in Agboville, he was belatedly naturalized as Ivorian in 2000, and elected national president of Côte d'Ivoire's Islamic Youth Association in 2006.

Since 1988, when the imams' board first coalesced, COSIM has organized nationwide mobilizations for Islamic holidays in order to observe the appearance of the moon and fix exclusive dates for celebrations throughout the country. ${ }^{50}$ Muslim communities of foreign origin now align themselves with media-relayed COSIM decisions. Launched in 2001, the Islamic FM station Radio Al Bayane was broadcasting in twenty-six languages in 2015, including English and some vernaculars spoken only by foreigners.

Revivalists have thus been careful all along to condemn ethnic- or nation-based chauvinism and resulting divisions, but also to value Muslim diversity as a rich heritage to be cultivated in the private sphere. What the revivalists argued was that this diversity ought not to obstruct the ever-increasing Muslim hopes for unity on matters of shared Islamic or national significance. The hope was that Muslims would set an example for the entire Ivorian nation - and for wider communities beyond - aiming to achieve greater cohesiveness and commensality among its citizens, while still respecting lawful expressions of sub-national differences. This hope echoes Anthony Appiah's idea of patriotic cosmopolitanism as a posture that takes into account the existence of difference(s) and the possibility of mutually beneficial conversations through differences, provided that these differences respect general ethical constraints (Appiah 1997: 621).

The revivalist discourse was a genuine, painstaking effort from within to allow the national Muslim community to reinvent itself and make a fresh start. If the consensus-prone memorial narratives that sing the praises of Muslim esprit de corps and universal ethics (as discussed in the first part of this article) fail to address the community's more complex history (in the second), it is because they never intended to produce careful historical analysis in the first place.

\footnotetext{
${ }^{49}$ Interview with Sékou Sylla, 25 August 2008.

${ }^{50}$ The exception is Tabaski (Id al-Adda), which is now scheduled to take place the day following Arafat station in Saudi Arabia, regardless of the appearance of the moon in Côte d'Ivoire.
} 
What these discursive accounts express, in their magnified and programmatic fashion, is precisely this new Muslim imaginary of a rebuilt community that rejects past mistakes and achieves internal and national vibrancy.

Without a doubt, public cosmopolitan patriotism was selective in its historiographical endeavour. But it is more than an enchanted vision: it is also grounded in facts. Revivalists were not ignorant of past Muslim xenophobia. Rather, they chose to speak of and enhance the more common but less audible story of cooperative relations among Muslims and between Muslims and their neighbours. They wished to reappraise those long-lived Muslim practices of conviviality and sharing with strangers, which Asef Bayat has characterized as 'everyday cosmopolitanism'. In tune with Ivorian revivalists, Bayat also critiques media, policy and academic circles for their excessive emphasis on human conflicts and the language of discord. It is high time, he argues, to focus anew on less boisterous but no less important occurrences of everyday cosmopolitanism, both as a scholarly enquiry and as an ethical project (Bayat 2008).

Revivalists' politics of memory was geared towards their reform-based objectives. Rather than rehearsing painful discords and condemning wrongdoing, Muslim elites emphasized past examples of proper behaviour in the hope that this pedagogy of emulation would be better conducive to change. Indeed, in the end, revivalists' public enunciation of rooted cosmopolitanism had some performative effects, playing its part in transforming Muslim society. It goes without saying that the relevance of ethnicity and nationality has not disappeared altogether within Muslim communities in Côte d'Ivoire. At times, local conflicts of older types still occur, which COSIM-CNI tries to solve. But compared with the period from the 1960s to the 1980s, when Muslims still occasionally expressed Dioula chauvinism or xenophobic feelings, the change is radical. Expressions of ethnic and national superiority are now deemed illegitimate in Muslim public space. Ostracism in all its guises has become politically incorrect. Today, the debate on whether to integrate foreigners into Ivorian society is perceived by most Dioula as tied to the debate about whether to integrate Islam into Ivorian society, state, and even history.

\section{EPILOGUE: WARS AND AFTER}

After years of brutal ivoirité discrimination, a coup d'état on 19 September 2002, led by mutineers of mostly Northern origin, failed to overthrow the government of President Laurent Gbagbo but managed to take hold of Northern territory, establishing its headquarters in Bouaké. Comparing the coup with the events of 11 September 2001, the born-again Gbagbo blamed local 'Islamic terrorists' for the violent disintegration of national unity. The allegation was simply false (see Miran-Guyon 2015). Guillaume Kigbafory Soro, the political leader of the 2002 armed rebellion, is a Catholic Sénoufo. There were no calls for jihad. So-called Forces Nouvelles rebels never spearheaded the cause of Islam nor did national Islamic institutions endorse the insurgency. What the new political circumstances in the North brought about on the religious front had less to do with Islam and more to do with the dozoya, the ways of the traditional Malinké or Sénoufo hunters, whose sudden rise to public prominence struck all Ivorians. Although 
many dozow (hunters; singular: dozo) were nominally Muslim, they were covered in amulets and feared for the power of their mystical arms. Imams denigrated them as 'fetishist' and appealed for conflict resolution and the revival of Muslim ways. Nonetheless, Gbagbo's indictments caused much physical and symbolic violence in the South; some imams were killed and others went into hiding or exile. Nearly all Islamic associations suspended their activities.

But when the warring parties signed the Ouagadougou peace agreement in March 2007, a few months after Cheikh Fofana's return from a four-year exile in the US to become head of COSIM, the Islamic institution pledged to make it a priority to contribute to the post-war reconstruction of the multi-ethnic nation and secular republican state. In this, imams joined other religious and civic actors.

Late in 2010, presidential elections were organized for the first time in ten years in the hope of bringing Côte d'Ivoire's crises to a close and of fostering peace and development. Laurent Gbagbo's refusal to accept the election of Alassane Dramane Ouattara led to a five-month 'post-electoral crisis' that was both costly in lives and dreadfully damaging to national cohesion. By and large, Islamic religious leaders were careful not to take a public position on the contentious poll out of the fear that it might worsen Muslims' situation. (It was with the greatest discretion that Cheikh Fofana, imam Samassi and other COSIM leaders ${ }^{51}$ took refuge in the Golf Hotel where Ouattara was leading his embargoed government under the protection of the United Nations.) When mosques were attacked and imams killed on an even greater scale than after 2002, the Conseil supérieur des imams issued clear media statements warning Muslims against retaliatory violence in the name of Islamic ideals and stating their concern about the possible drift towards a religious war. Gbagbo was eventually arrested in April 2011 and later transferred to the International Criminal Court. Alassane Ouattara was officially installed as president in May: it was the first time in Côte d'Ivoire's history that the country's president was nominally Muslim (though actually secular and with a substantial entourage of Freemasons). Along with a Catholic bishop and a traditional king, Cheikh Fofana was appointed as a vice president to the Commission Dialogue Vérité et Réconciliation (CDVR), which was designed to heal Ivorian wounds. A few years on, many Southern natives and political opponents condemn the alleged drift of the Ouattara regime towards Dioula chauvinism and exclusion. There is a gap between the two social imaginaries of a cohesive Muslim community and solidary nation and the efforts to make both a reality. In these gaps lie the most acute tensions of socio-political life in post-crisis Côte d'Ivoire.

\section{ACKNOWLEDGEMENTS}

Many warm thanks to John Saul for his help in upgrading my English, and to the two anonymous readers of this article for their generous and apposite advice in sharpening the argument.

\footnotetext{
${ }^{51}$ By then, Koudouss Idriss Koné, CNI's president, was siding with Gbagbo (see Miran-Guyon 2015).
} 


\section{REFERENCES}

African Studies Review (2006) 'Special issue: Autochthony and the crisis of citizenship', 49 (2).

Akindès, F. (2004) The Roots of the Military-Political Crises in Côte d'Ivoire. Research report 128. Uppsala: Nordiska Afrikainstitutet.

Akindès, F. (2009) 'Côte d'Ivoire since 1993: the risky reinvention of a nation' in A. R. Mustapha and L. Whitfield (eds) Turning Points in African Democracy. Oxford: James Currey.

Appiah, K. A. (1997) 'Cosmopolitan patriots', Critical Inquiry 23 (3): 617-39.

Ba, T. (2000) Le Mufti El Hadj Ahmed Tidjani Ba. L’homme et l'érudit. Abidjan: Centre d'édition et de diffusion africaines (CEDA).

Banégas, R. (2006) 'Côte d'Ivoire: patriotism, ethnonationalism and other African modes of self-writing', African Affairs 105 (421): 535-52.

Bayat, A. (2008) 'Everyday cosmopolitanism', ISIM Review 22: 5.

Bruckner, P. (1986) 'Le cosmopolitisme comme débris', Communications 43: 117 26.

Chauveau, J.-P. and J.-P. Dozon (1985) 'Colonisation, économie de plantation et société civile en Côte d'Ivoire', Cahiers Orstom, Série Sciences Humaines 21 (1): 63-80.

COSIM (2007) 'Actes de la deuxième conférence ordinaire des imams'. Conseil supérieur des imams (COSIM), Abidjan, 27-29 April.

Dembélé, O. (2002) 'La construction économique et politique de la catégorie "étranger" en Côte d'Ivoire' in M. Le Pape and C. Vidal (eds) Côte d'Ivoire. L'année terrible 1999-2000. Paris: Karthala.

Dozon, J.-P. (1997) 'L'étranger et l'allochtone en Côte d'Ivoire' in B. Contamin and H. Memel-Fotê (eds) Le modèle ivoirien en questions: crises, ajustements, recompositions. Paris: Karthala-Orstom.

Dozon, J.-P. (2011) Les clés de la crise ivoirienne. Paris: Karthala.

Fofana, L. (2007) Côte d'Ivoire: Islam et sociétés. Contribution des musulmans à l'édification de la nation ivoirienne (XIe-XXe siècles). Abidjan: Centre de recherche et d'action pour la paix (CERAP).

Gary Tounkara, D. (2005) 'La communauté musulmane et la quête de l'égalité politique dans la Côte d'Ivoire de l'ivoirité (1993-2000)' in M. Gomez-Perez (ed.) L'islam politique au sud du Sahara. Identités, discours et enjeux. Paris: Karthala.

Gary Tounkara, D. (2008) Migrants soudanais/maliens et conscience ivoirienne: les étrangers en Côte d'Ivoire (1903-1980). Paris: L'Harmattan.

Geschiere, P. and B. Meyer (eds) (1999) Globalization and Identity: dialectics of flow and closure. Oxford: Blackwell Publishers.

Hanretta, S. (2009) Islam and Social Change in French West Africa: history of an emancipatory community. Cambridge: Cambridge University Press.

Kane, O. (2007) 'Moderate revivalists: Islamic inroads in sub-Saharan Africa', Harvard International Review 29 (2): 64-8.

Konan, V. (2005) Robert et les Catapila. Nouvelles. Abidjan: Nouvelles éditions ivoiriennes (NEI).

Konan, V. (2009) Les Catapila, ces ingrats. Paris: Jean Piccolec.

Kourouma, A. (1990) Monnè. Outrages et défis. Paris: Éditions du Seuil. 
Labazée, P. (1993) 'Les échanges entre le Mali, le Burkina Faso et le nord de la Côte d'Ivoire' in P. Labazée and E. Grégoire (eds) Grands commerçants d'Afrique de l'Ouest. Logiques et pratiques d'un groupe d'hommes d'affaires contemporains. Paris: Karthala-Orstom.

Launay, R. (1979) 'Landlords, hosts, and strangers among the Dyula', Ethnology 18 (1): 71-83.

Launay, R. (1992) Beyond the Stream: Islam and society in a West African town. Berkeley and Los Angeles CA: University of California Press.

Launay, R. (1996) 'La trahison des clercs? The "collaboration" of a Suwarian 'alim' in J. Hunwick and N. Lawler (eds) The Cloth of Many Colored Silks. Evanston IL: Northwestern University.

Launay, R. (1997) 'Des infidèles d'un autre type. Les réponses au pouvoir colonial dans une communauté musulmane de Côte d'Ivoire' in D. Robinson and J. L. Triaud (eds) Le temps des marabouts. Itinéraires et stratégies islamiques en Afrique occidentale française, v. 1880-1960. Paris: Karthala.

Launay, R. (2005) 'Islam and civil strife in Côte d'Ivoire'. Paper presented at the African Studies Association annual meeting, Washington DC, 17-20 November.

Launay, R. (2012) 'The roots of Islamophobia in Côte d'Ivoire', Cultural Anthropology, 16 February <http://www.culanth.org/fieldsights/200-the-rootsof-islamophobia-in-cote-d-ivoire>, accessed 3 March 2012.

Launay, R. and M. Miran (2000) 'Beyond Mande Mory: Islam and ethnicity in Côte d'Ivoire', Paideuma 46: 63-84.

LeBlanc, M. N. (1999) 'The production of Islamic identities through knowledge claims in Bouaké, Côte d'Ivoire', African Affairs 98 (393): 485-519.

LeBlanc, M. N. (2000) 'From ethnicity to Islam: social change and processes of identification amongst Muslim youth in Bouaké, Côte d'Ivoire', Paideuma 46: 85-109.

LeBlanc, M. N. (2003) 'Between ethnicity, religion and citizenship: young Muslims in Côte d'Ivoire' in C. Coquery-Vidrovitch, O. Goerg, I. Mandé and F. Rajaonah (eds) Etre étranger et migrant en Afrique au XXe siècle. Enjeux identitaires et modes d'insertion. Paris: L'Harmattan.

Loimeier, R. (2003) 'Patterns and peculiarities of Islamic reform in Africa', Journal of Religion in Africa 33 (3): 237-62.

Marshall-Fratani, R. (2006) 'The war of "who is who": autochthony, nationalism, and citizenship in the Ivorian crisis', African Studies Review 49 (2): 9-43.

Mbembe, A. (2002) 'African modes of self-writing', Public Culture 14 (1): 239-73.

McGovern, M. (2011) Making War in Côte d'Ivoire. Chicago IL: Chicago University Press.

Memel-Fôté, H. (1999) 'Un mythe politique des Akan en Côte d'Ivoire: le sens de l'État' in P. Valsecchi and F. Viti (eds) Mondes akan. Identité et pouvoir en Afrique occidentale. Paris: L'Harmattan.

Miran, M. (2002) 'African mullahs: the development of Shi'a Islam in contemporary Côte d'Ivoire'. Paper presented at the fifth international conference of the Mande Studies Association, Leiden, 17-21 June.

Miran, M. (2006a) Islam, histoire et modernité en Côte d'Ivoire. Paris: Karthala.

Miran, M. (2006b) 'The political economy of civil Islam in Côte d'Ivoire' in M. Bröning and $\mathrm{H}$. Weiss (eds) Politischer Islam in Westafrika. Eine Bestandsaufnahme. Berlin: Friedrich Ebert Stiftung and LIT Verlag. 
Miran-Guyon, M. (2012) "Native" conversion to Islam in Southern Côte d'Ivoire: the perils of double identity', Journal of Religion in Africa 42 (2): 95-117.

Miran-Guyon, M. (2014) 'Gloire et déboires de la laïcité en Côte d'Ivoire au prisme de l'imaginaire social musulman' in G. Holder and M. Sow (eds) L'Afrique des laïcités. État, religion et pouvoirs au sud du Sahara. Paris and Bamako: Institut de recherche pour le développement (IRD) and Éditions Tombouctou.

Miran-Guyon, M. (2015) Guerres mystiques en Côte d'Ivoire. Religion, patriotisme, violence (2002-2013). Paris: Karthala.

Miran-Guyon, M. and M. Touré (2012) 'Islam, autorité religieuse et sphère publique en Côte d'Ivoire. La figure emblématique du cheikh Aboubacar Fofana' in O. Goerg and A. Pondopoulo (eds) Islam et sociétés en Afrique subsaharienne à l'épreuve de l'histoire. Un parcours en compagnie de Jean-Louis Triaud. Paris: Karthala.

N'Goran-Poame, L. M. L. (2007) 'Aux fondements de la crise ivoirienne: le plurilinguisme', Repères 'International' [Bouaké]: 83-94.

Person, Y. (1982) 'Islam et décolonisation en Côte d'Ivoire', Le Mois en Afrique 198-199: 14-29.

Politique Africaine (2000) 'Special issue: Côte d'Ivoire, la tentation ethnonationaliste', 78.

Politique Africaine (2008) 'Special issue: Enjeux de l'autochtonie', 112.

Savadogo, M. (2005) 'L'intervention des associations musulmanes dans le champ politique en Côte d'Ivoire depuis 1990' in M. Gomez-Perez (ed.) L'islam politique au sud du Sahara. Identités, discours et enjeux. Paris: Karthala.

Touré, V. (2008) Les organisations pionnières des intellectuels musulmans de Côte d'Ivoire. Abidjan: Les Classiques Ivoiriens.

Triaud, J. L. (1974) 'La question musulmane en Côte d'Ivoire (1893-1939)', Revue d'Histoire d'Outre-Mer 225: 542-71.

Triaud, J. L. (forthcoming) Musulmans de Côte d'Ivoire en situation coloniale. Un parcours à travers l'histoire ivoirienne, 1880-1960.

Tuho, C. V. (1984) J'ai changé de nom ... Pourquoi? Abidjan: Nouvelles éditions africaines (NEA).

Werbner, P. (ed.) (2008) Anthropology and the New Cosmopolitanism: rooted, feminist and vernacular perspectives. Oxford: Berg.

Werbner, R. (2008) 'Responding to rooted cosmopolitanism: patriots, ethnics and the public good in Botswana' in P. Werbner (ed.) Anthropology and the New Cosmopolitanism: rooted, feminist and vernacular perspectives. Oxford: Berg.

Yacoob, M. (1980) 'Ahmadiyya: urban adaptation to the Ivory Coast'. PhD thesis, Boston University.

Zolberg, A. R. (1964) Ivory Coast: one party government. Princeton NJ: Princeton University Press.

\section{ABSTRACT}

The nativist ideology of ivoirité of the 1990s generated brutal discriminatory policies against those labelled as 'strangers', especially Muslims. Reversing that perspective, this article focuses on the interface between religion and national identity in twentieth-century Côte d'Ivoire from within Muslim society. The argument is 
divided into two parts. The first puts forward the counter-hegemonic, patrioticcum-cosmopolitan narratives that a new Muslim leadership formulated in order to write Islam into national history. The second focuses on grass-roots, demotic, day-to-day realities. It explores Muslim takes on belonging and alienation in practice, paying careful attention to the community's internal diversity. It shows how, over time, Ivorian Muslims have showcased varying degrees of cosmopolitan patriotism but also of their own, local xenophobia. The concluding section returns to the new Muslim leadership and its multifaceted endeavours to reconcile Muslim lived experiences with their cosmopolitan patriotic aspirations. The article ends with a short epilogue surveying the violent armed conflicts of the period 2002 to 2011 and how Muslims were a part of them.

\section{RÉSUMÉ}

Conçue dans les années 1990, l'idéologie de l'ivoirité a généré des politiques discriminatoires à l'encontre des dits 'étrangers' et spécifiquement des musulmans. L'article opère un renversement de perspective en interrogeant l'interface entre religion et identité nationale dans la Côte d'Ivoire du XXe siècle au prisme des acteurs musulmans. Le propos est divisé en deux parties. La première partie présente les narratifs contre-hégémoniques, patriotico-cosmopolites, qu'une nouvelle élite musulmane a élaborés pour inscrire l'islam dans l'histoire nationale. La seconde partie se penche sur les réalités ordinaires du vécu local au quotidien. Elle explore les pratiques musulmanes concrètes d'inclusion et d'exclusion, en prêtant attention à la diversité interne des communautés. Elle expose comment les musulmans ivoiriens ont fait montre à travers le temps de différents degrés de patriotisme cosmopolite mais aussi de xénophobie. La conclusion revient sur le nouveau leadership musulman et leurs efforts multiformes pour réconcilier le vécu musulman avec leurs aspirations patriotico-cosmopolites. Un bref épilogue chronique les violents conflits armés de 2002 à 2011 et la part qu'y ont prise les musulmans. 